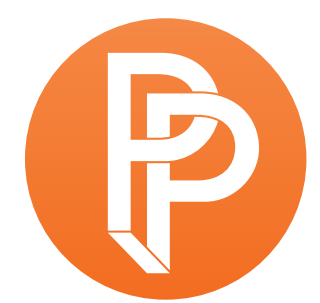

PERFORMANCE

PHILOSOPHY

\title{
THE PHYSICAL CONSEQUENCE TO KNOWING: A SPECULATIVE REPORT
}

\section{PAVLEHEIDLER FREELANCE DANCER, WRITER, AND DANCE SCHOLAR}

Reality does not depend on the prior existence of human beings; rather, the point is to understand that 'humans' are themselves natural phenomena.

Karen Barad $(2007,336)$

Even within the women's movement, we have had to fight and still do, for that very visibility which also renders us most vulnerable, our Blackness. For to survive in the mouth of this dragon we call america, we have had to learn this first and most vital lesson--that we were never meant to survive. Not as human beings. And neither were most of you here today, Black or not. And that visibility which makes us most vulnerable is that which is also the source of our greatest strength. Because the machine will try to grind you into dust anyway, whether or not we speak. We can sit in our corners mute forever while our sisters and ourselves are wasted, while our children are distorted and destroyed, while our earth is poisoned; we can sit in our safe corners mute as bottles, and we will still be no less afraid.

Audre Lorde ([1977] 2017, 3-4)

And I suppose that the saddest thing for me, thinking about the cover version that is Oranges, is that I wrote a story I could live with. The other one was too painful. I could not survive it.

Jeanette Winterson $(2012,6)$ 
the physical

consequence

to knowing,

a

speculative

report 
I dance for a living. I have danced in some shape or form since I was born. I've danced before I could walk. This is evidenced by a home-video which pictures me dancing in diapers whilst holding on to the couch because, and you can see this clearly, I can barely stand on my own.

I've earned my first salary dancing at the age of eight. My first job was in the show-dance circuit, I specialised in stage and television. I left this circuit after five years for what I perceived to be a lack of content. The general consent was that what you could do once, you did again, day in and day out, you were compensated and celebrated for your service, and that was that. In other words, that you could do something impressive reliably and on request was probably the reason why you were given another chance. And another. And another. Meanwhile, all the repetition didn't mean that we were encouraged to engage with the form in the fashion of a martial art, or anything like that. The work was earning me money at an age when one is not expected to have access to anything more than a weekly allowance with which to buy a magazine and some gum and yet all I could think of was how cheap earning money in the context I was earning money in made me feel.

At the age of thirteen I left the show-biz circuit and joined the youth dance program at the Zagreb Youth Theatre. I started learning about dance history, started dancing in theatre and dance performances for children and adults; my first role was in the 40-minute-long dance rendition of Mozart's The Magic Flute choreographed by Desanka Virant. Following, I was playing characters and not, I was telling stories and not. I danced in original works and in repertory pieces. At the age of 15, I started training with Studio, Contemporary Dance Company. My first professional gig, later that same year, was in Matjaž Farič's rendition of The Rite of Spring. That same Rite of Spring, I was learning, which in 1913 was said to have disturbed the Parisian audiences to the extent that was still worth talking about. That we were working on a historically relevant piece meant the world to me.

Having found access to a continual influx of information, dancing started feeling purposeful again. In comparison to show, art felt investigative, negotiable, radical. In comparison to getting applause every time, mixed reactions felt relevant, asked for my attention, made me think twice about what I was doing: before and after I did it. This kind of investigative approach to working as a dancer made sense to me. It still does.

At the age of seventeen I left my home country because, at the time, there was no higher education for dance and choreography in Croatia. People, professionals and non-professionals alike, asked why it was that I wanted to "go back to school." I didn't know how to respond to that question for I hadn't had the feeling I was "going back." If anything, I was going forwards, I was going north and I was going west, I was leaving home, I was looking for ever more information. I was driven by curiosity, a thirst for knowledge, and a thirst for experiencing.

Dancing has always been the reason I made what other people called bold choices in life. Personally, however, I didn't think much about any of it. I did what I had to do to learn as much as I could about this field I was navigating. I went where information could be found. Dancing being an oral tradition and a practical one, I went to where the people "who knew" were; where they lived, taught, and created. I left Croatia for Austria, where I spent two years studying at the Salzburg 
Experimental Academy of Dance. I left Austria for Belgium, where I spent four years studying at the Performing Arts Research and Training Studios. I eventually moved to Sweden, where I still live and work. It is here that I took the Master Program in Fine Arts entitled New Performative Practices. After eight years studying dancing and choreography in prestigious dance schools, I decided that what I was studying was not so much dancing as it was studying dancing. This report draws heavily from my experience studying dancing in these schools. I also draw from my experience teaching dancing and working as a dancer in Croatia, Austria, Germany, Belgium, the US, Canada, and Aotearoa New Zealand since approximately 2005 until today.

Years into traveling, dancing, making dancing, teaching dancing, studying dancing, and writing dancing, years into watching repertory and original work, participating in making of original work and studying of repertory, years into studying the European theatrical dance circuit, of both dance production and dance education, I started noticing patterns. What I thought was a radical art from, this art of embodiment of thought was, I was learning, mostly not radical at all. It was also mostly not studying embodiment, in the sense of the word I will attempt to argue for. For the largest part the art of stage and theatre dancing and making was and is, in fact, an artform of obedience.

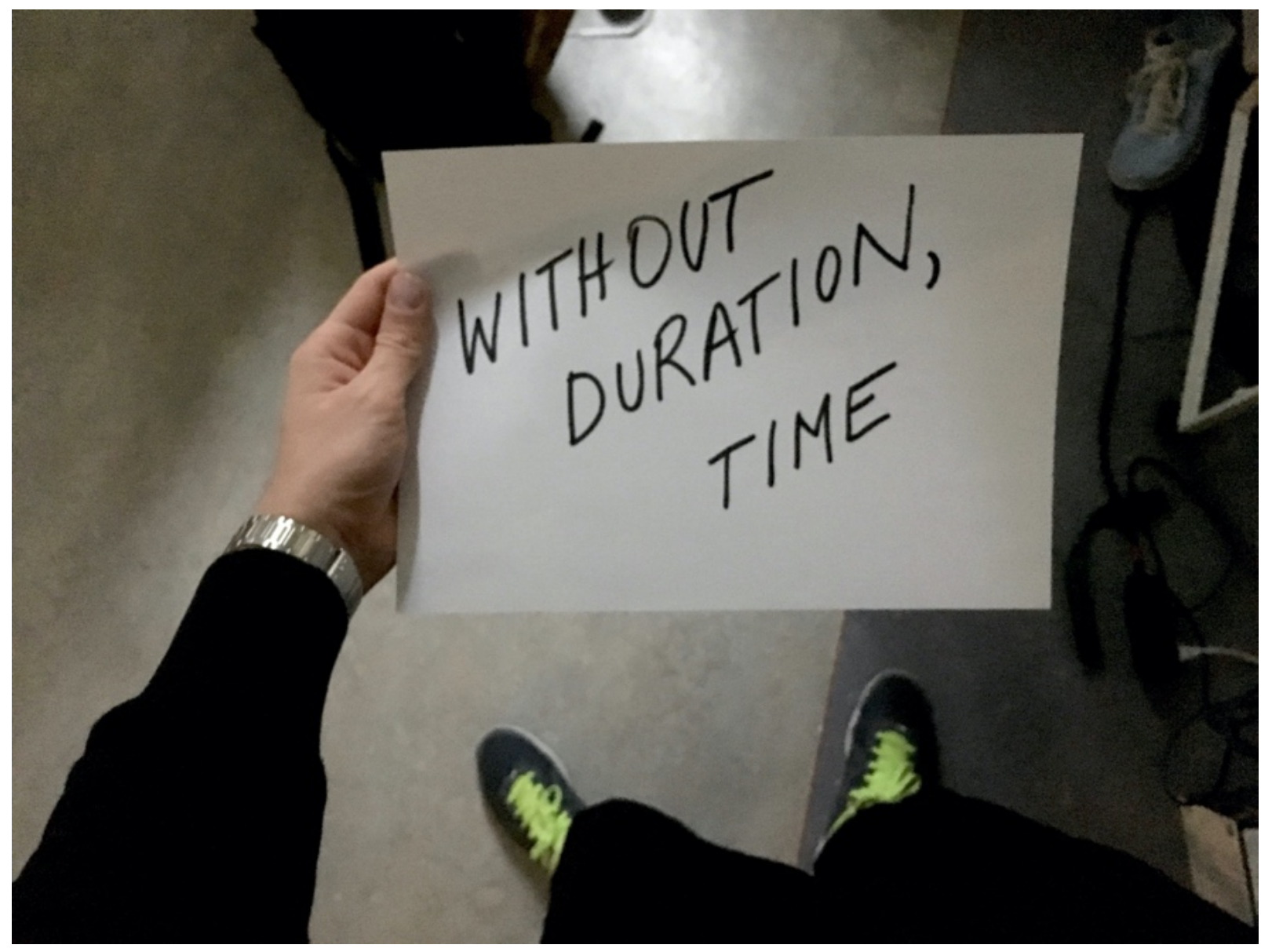


Stockholm, 2017.

When a 19 year old person came to the university I teach at to study dance performance and, upon being asked to share their opinion in front of class, started crying because of how stressed they were-having never before been asked to share their opinion in public--I got distracted from teaching, I stopped the class. I stopped the class because: (1) I had to investigate: could it have been that a dance school taught their students dance at high-school level in 2016 in silence; and (2) I had to make sure this person's personhood got acknowledged and--for once, perhaps--became a priority before all else institutional, social, and politically correct. ${ }^{1}$

We stood together, in front of class, the person and I, hand in hand for minutes on end, until tears transformed into a soft giggle, and until they said--out loud, calmly, and in public--the word: "Soup." Their peers followed in a procession, one by one they took the imagined spotlight to say random words. "Banana." "Shoe." "Airplane." To growing comfort and growing confidence I responded by raising the stakes. Random words were followed by the word "artist," then "I." Then "I am." "I am" was difficult, it raised a lot of questions. "I am?" We waited. Repeated. "I am?" transformed into "I am." and was conquered. And then finally, after a couple of hours we were going to spend dancing, the person who inspired the becoming ritual took the spotlight and said--confidently and loudly, undoubtedly--the statement: "I AM AN ARTIST."

$$
\begin{aligned}
& \text { observation } \\
& \text { reflection } \\
& \text { speculation }
\end{aligned}
$$




$$
\begin{array}{r}
\text { reference } \\
\text { experience } \\
\text { document } \\
\text { (n) -ation }
\end{array}
$$

Dance programs, by and large, do not prioritise theoretical and critical practices. If theory stands represented in the curriculum, rarely is any time scheduled for reading and writing. Reading and writing, as it were, are meant to be engaged with after hours, in the evenings or during the weekends: i.e., after the dancer has already spent a minimum of 40 hours a week engaged in selfreflective physical labour.

It is questionable, however, if the time for reading and writing is, in fact, considered by those responsible for putting curricula together. Because how do you argue the lack of scheduled time? Either by saying that students, whilst meant to develop a theoretical practice, are not actually meant to be able to do so within the framework of a 40-hour week? Or else by saying that the students are expected to engage a massive professional undertaking as private individuals, or else be expected to fail as professionals? 
Meanwhile, most people who teach theory to dancers in my experience are professional academics who do not necessarily know what it's like to be spending the majority of your scheduled time in the dance studio engaging in heavy physical labour. Most people who teach theory to dancers are people who've, in the process of studying theory, studied reading and writing, much in the same way dancers have, in the process of studying dancing, studied dancing: without having to explain what it takes to engage in the act of reading or dancing over an extended period of time, without having to make the practice interesting or accessible to someone who doesn't already have the interest or the access. The practice of reading, as is the practice of dancing, is so discovered to be assumed to be self-evident and is discovered to be assumed to be something a student has already accomplished, so to speak, for how else did they manage to qualify to enter a BA program in the first place? For example. I wonder, however, if the tables were turned, would we expect students of philosophy to be able to dance in the way we expect students of dance to be able to read?

In the context of studio practice in general dancers are mostly working in groups, are mostly learning by imitating (if not the teacher than the [over-romanticised aesthetic] dream) and are, crucially, mostly spoken to. Speaking, in general and coming from a dancer, is widely considered to be inappropriate in the context of a dance class. This is not evidenced only in a teacher's behaviour, which I will not be bringing up as an example because I do not wish to, at present, problematise individual choice making. More importantly, then, I am interested in the fact that the inappropriateness of a dancer to speak in a dance class is evidenced in the general structure of a dance class, the flow of which is based on its uninterrupted ongoingness. Uninterrupted ongoingness is often what makes a class good, and a teacher who is able to maintain the status quo-a guru.

\section{Intra-action:}

In that they are spoken to, dancers are given access to information. In that they are rarely asked to speak, their reflective process--assuming that they, indeed, engage in one--remains unwitnessed. I say "assuming that they, indeed, engage in one" not to question dancer's capacities and/or interest in engaging in a reflective process, but rather to point out (1) that dancers are rarely given the opportunity to share their reflective process in public; and (2) that dancers are rarely given the opportunity to spend time reflecting in any documentable way. What you will often see is a teacher speaking to a dancer then immediately shifting attention to another dancer, in which case the first dancer carries off on their own; or else you will see a teacher speaking to a dancer then immediately asking the dancer to demonstrate in action that they've processed the information, in which case the dancer has no time to reflect on their own, no time to engage in a 
process of trial and error, no time to study between the reception of information and the demonstration of its implementation.

But even if a dancer is given the time to study, what remains is the following assumption: that whenever a dancer demonstrates that they've implemented given information--the teacher will be able to tell. A dance teacher may be able to perceive a dancer's performance as knowledgeable in a specific way, no doubt about it. My point is the following: if there is no dialogue; if the dancer never speaks, i.e., reports on their internal process, and if the teacher never explains what of what they've seen, felt, intuited is informing their evaluation, then we not only risk not knowing that the dancer actually engaged in a reflective process (in which case we're risking not acknowledging the dancer's agential efforts), but we also risk not knowing what conclusions the teacher has come to, how they have come to them, and in order to achieve what purpose. We risk not exposing the thinking process in mediums other than the unspoken ones, and so fail to develop a shareable and teachable methodology. In other words, we risk not learning how to engage in a critical study of embodiment, and we risk not learning how to engage in a critical study of performativity--a study of that which is interlinked with yet separate from itself.

The point, you could argue, is, of course, not that we are risking, but that we have, in fact, already risked. We have already created and embodied the culture of silence within the context of European dance making and teaching.

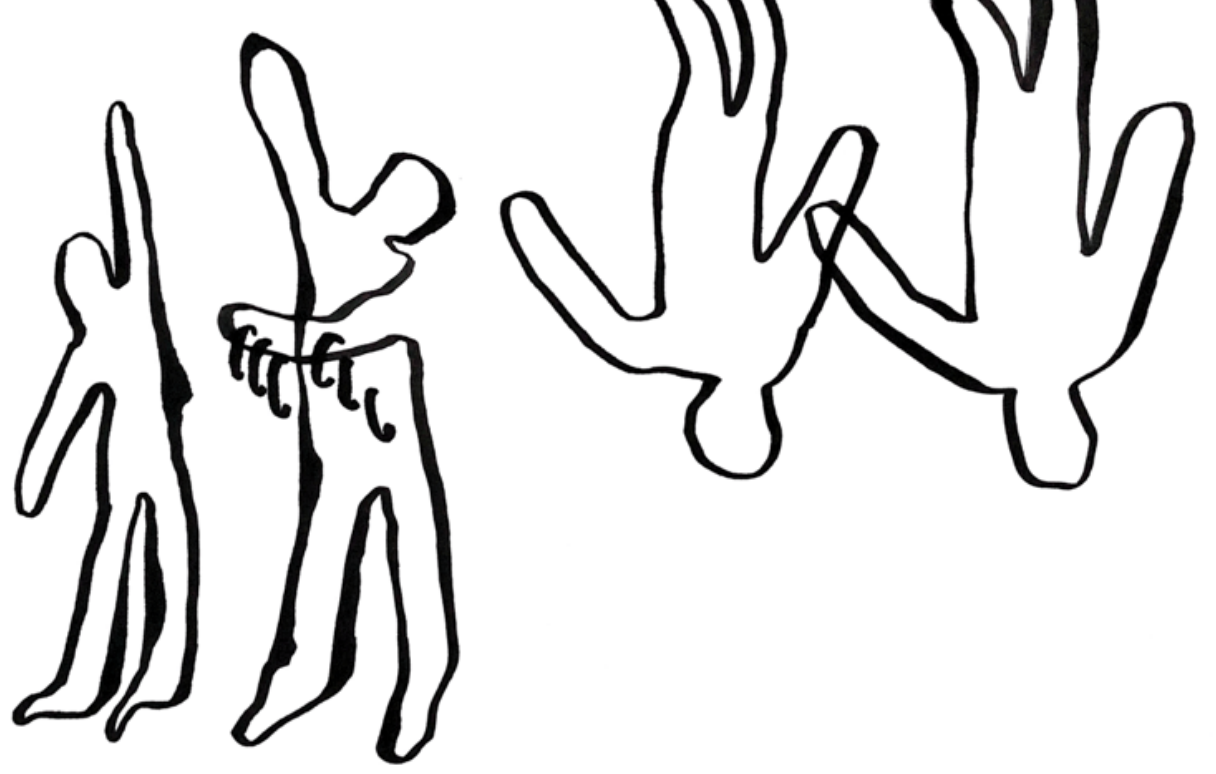


I witness (repeatedly) the word "talent" used when describing the indescribable; when describing something that comes easy, looks effortless, and is perceived as virtuosic--all at the same time. I also witness the word talent used when the talent does one of the two: (1) doesn't speak about itself publicly (unsurprisingly); or: (2) does speak about itself publicly, but in such a way that does little more than reproduce a stereotype, i.e., fits within the framework of the dominant narrative of how talent comes about and why its existence is admirable.

Artists who speak and speak in complex ways about the work that they're doing are often spoken about in reference to the words "experiment," "activism," and/or "research" art, but only if an "expanded" notion exists and "we" are familiar with it, such as "choreography as an expanded practice." Artists and works of the sort are often assumed to be not interesting to the general population, or to be belonging to a niche.

Notions like talent, I dare say, have, traditionally speaking, made it possible for skilled individuals to forgo developing a critical understanding of their skills. Notions like talent have also made it possible for people in power to make decisions without having to justify their process more than by saying that they recognised or did not recognise talent. Notions like talent have made it possible for teachers to favour students, for audiences to favour dancers or choreographers--without anyone being the wiser for it.

Note: My aim is not to abolish talent, which has, like the word beauty, named wonderful things in the past. Instead, I'd like to see such a word examined on a cultural and a personal basis, I would like to see it used with more care, I would like to see it used with more purpose, and I would like to hear it defined more often. Yes, talent, but what does that word mean? When in use, why is it being used, specifically?

The order described above is not only found in the educational environment. It is also found in the professional environment. The dancer-teacher dynamic is reflected in professional relationships established between dancers and rehearsal directors, dancers and artistic directors, and dancers and choreographers. The consequences of this order are innumerable.

In my experience of navigating the European professional field of dance and choreography, a field that seems to think itself post-modern in every way imaginable, what I seem to be meeting is a culture and a tradition of knowledge production that, at least where I live and work still largely assumes, amongst other things, the dominance of the (Elightened) mind over the (sacrilegious) body. My goal with this essay is to account for some of the ways in which I think I recognise how this assumption has been institutionalised, and as such frames what is possible to perceive and argue as knowledge. I will also try to articulate why embodied practices are especially vulnerable within this context. 
In the Western tradition, a consensus-of-sorts has been made, historically speaking, due to which learning and consequently knowledge are assumed to be an objective process related to thinking, which, in turn, is commonly understood to be taking place in the thinking mind, i.e., to be a capacity of the central nervous system. Descartes, who is arguably the primary reason this consensus exists, banished thinking from all bodily systems that are not the brain, including all the capacities of the nervous system that are not oriented towards thought calibrated through language, when he said that he "decided to suppose that nothing was such as they [the senses] lead us to imagine to be" "because our senses sometimes deceive us" ([1637] 2006, 28).

This is to argue that what Descartes did was not only to create the infamous split. He created a system that stigmatises any order of thought other than doubtful (objective) and documentable (written) thought (language). A system that, it is needless to argue, subordinates any and every system that is oral or non-verbal, that is possibly intuitive, any and every academically undocumented study, no matter its longevity or otherwise recognised credibility. Furthermore, and this in contradiction to what I am about to explore in this text, Descartes created the second brain, one that is not, in fact, an organ at all, but lives, as an actor, in language alone.

\begin{abstract}
Traditionally, in our culture, learning is considered to be a function of the nervous system. It is my experience that the nervous system is only one aspect of learning-that it is first a recording system and therefore the last system to "know." It records and stores patterns of movement and behaviours and, once stored, it can retrieve them and thereby control experience through habit, memory, and projection. [...] For new experience to be obtained, release of the nervous system control is necessary so that old habits are no longer directing the outcome and new cellular experience can come into being. (Bonnie Bainbridge Cohen 2012,161)
\end{abstract}

\begin{abstract}
Embodied practice is epistemic. It is structured by and productive of knowledge. Accordingly, an epistemological account of embodied practice is one according to which such practice actively encounters and comes to know reality through technique, rather than simply producing or constructing it. Social epistemologies allow us to analyse the development and circulation of embodied knowledge--in the form of technique--through processes that are both socially enabled and materially engaged. (Ben Spatz 2015, 27)
\end{abstract}

I turn to Body-Mind Centering ${ }^{\circledR}$, the school of embodied anatomy initiated by Bonnie Bainbridge Cohen that takes an embodied approach to studying and affirms the person's experience as the paradigm within which to think. The kind of pedagogy the school stands for prioritises--without deviation, I'd like to argue--the embodied understanding and builds a theoretical and critical knowledge upon it. Here is an example of a methodology that reverses the Cartesian paradigm, revolts its hierarchy of priorities, in practice as it starts from the body, and works its way to the brain, all the while questioning its assumed supremacy. 
A student of Body-Mind Centering ${ }^{\circledR}$ studies always at their own pace, even when studying in a group. This means that the flow, the "uninterrupted ongoingness" a dance class will be celebrated for, is--depending how you choose to look at it--either non-existent in the context of a BMC $®$ class or else exists but is defined by a set of parameters unimaginable from the point of view of a tradition whose primary focus is, perhaps, obedience.

It is customary, in a BMC® class, for the class to be interrupted. It is customary for questions to arise, for people's workflow to be interrupted, and for books to be put down. It is customary for the exercises to take more time than anticipated and it is customary for the teacher to be renegotiating their plans in real time. Meanwhile, you will frequently find a student of BMC $®$ taking a nap in class or interrupting their day to write an entry in their journal or take a walk. This is the kind of behaviour, namely, a dance student might be disciplined and even expelled for. This is also the kind of behaviour that an adult who ordinarily subscribes to a normative lifestyle will find disturbing, or at least dissatisfyingly unfamiliar. In short, it's the kind of behaviour that requires time for adjustment, it requires getting used to. It is one thing to know, after all, that napping is allowed when necessary. It is an entirely other thing for the individual to actually know themselves well enough to know when it's time to take a nap, then take it; and for the community to embrace the presence of napping bodies within the educational context without having to justify, evaluate, or pass judgement.

What this pedagogical methodology proposes is an educational order in which a group will never accomplish anything that isn't first accomplished by all its members. It proposes a standard that reverses currently dominant evaluative criteria, as it denies the teacher the capacity to decide what the student is to perform without negotiation. Each step in this order is a matter of negotiation of each member of the group in relation to each other member, no matter their rank.

\section{calibration}

\section{jurisdiction}

or how to reverse the mind-body split 
In terms of Body-Mind Centering ${ }^{\circledR}--$ and I'm developing and reporting on my own understanding of the embodied knowledge I am tending to in the context of my ongoing study--every cell of the human body has "a mind of its own." One way of understanding "the mind of a cell" is not metaphorical, but literal. Namely, every cell has a nucleus, and in that nucleus the information from which it recognises or draws its purpose. Were I opposed to personification, I could say the same thing differently: Every cell has a nucleus in which is stored the information that corresponds to or aligns with the cell's function. I am, of course, at this instance talking about the programming, I am talking about the code, I am talking about the DNA.

In that a cell has the information it needs to be able to know its purpose under its own jurisdiction-is how I started thinking about it--a cell is independent. It governs itself, and only reports to the central nervous system, which is, in turn, dependent on the input provided by cellular life external to itself. This implies a reversal of the dominant narrative by which the only experience of value is that had when the mind governs the body.

The Central nervous system, contrary to the popular opinion, is not in charge. Its primary functions include, according to my understanding of $B M C \circledR$, recording, organising, and storing. According to the Department of Molecular and Cell Biology at UC Berkeley's online resource, the primary functions of the central nervous system are "integrating the sensory information and directing any necessary response."

Experiencing, by which I mean gathering of new information, happens where body and environment meet. In that it happens through interaction, experiencing happens through sensory perception, which means that it necessarily happens at a cellular level. According to UC Berkeley's online resource, "afferent or sensory neurons collect stimuli received by receptors throughout the body, including the skin, eyes, ears, nose, tongue as well as pain and other receptors in the internal organs." In that experiencing of the world happens at a cellular level, the experiencing of the world happens, and this is a very important point for me to make, outside of the jurisdiction of the nervous system. More importantly, the experiencing of the world happens "outside" of the jurisdiction of that bodily system that we've, culturally speaking, learned to associate with control and... identity, I suppose, is what's at stake here, isn't it? The other implication here is that to learn something new one, quite literally, needs not to rely on the capacities of the Cartesian mind--which is, without the interference of the interactive thus sacrilegious body, as it's suggested here, confined to the world of information that was collected sometime in the past, possibly under uncontrolled circumstances (what about: bias). 
A cell, any cell, may be sensitive to the nervous system. A cell might also be sensitive to its cluster. A cell might also be sensitive to its cluster only, and it could be that it's the cluster, but not the cell itself, that is sensitive to the nervous system.

Wherever there's a cell sensitive to a cell, a cluster, or the nervous system, the nervous system, a cluster, or a cell is, in turn, sensitive to the cell. 
This is my first attempt at approaching the notion of agency as a practice. I am looking for a way of releasing bodily capacities from the jurisdiction of the mind, as understood within European paradigms. I start by affirming the mind-body split as most people I have the chance to work with and teach exhibit in one way or another proof of the fact they've embodied the concept. All the while, I am considering philosophical texts, anatomical texts, and (science) fiction; I am taking into account my bodily experience, I am dancing and I am writing, I am teaching, conversing, occasionally making progress, occasionally falling back on old habits, making unnecessary assumptions, and failing. My strategy includes not trying to fix anything but to study every step I am taking; every achievement, every set-back. I assume my learning curve to be cyclical, as I continue to practice in public, always vulnerable but available to receiving feedback. 
A possible consequence of thinking one cell a complete living organism is thinking all cells as complete living organisms is thinking human as a conglomerate made up of trillions of living organisms. A possible consequence of thinking one cell a complete living organism is thinking human as a conglomerate made up of trillions of living organisms whose lifespans are, in most cases, significantly shorter than the human's; organisms that are born and that die how many times during a human life cycle--much to the human's personal satisfaction, right? A possible consequence of thinking one cell a complete living organism is thinking human a result of labour the human needs not be aware of even, even though every decision the human makes for themselves has an immediate effect on the conditions that govern cellular life, as cells depend on the human breathing, eating, sleeping for all kinds of reasons, including nourishment--all of which, the breathing, the eating, the sleeping, the human, in turn, needs to be able to afford.

I am talking politics here. I am talking about an opportunity to think global politics on the scale of a single human individual. To do this, I don't even need to develop a metaphor. I only need to study anatomy, is my proposal. And not just study, objectively speaking, but study, subjectively speaking.

Meanwhile, humans, in their blissful state of ignorance, assume life as a given, and death as something to avoid--both experientially and in conversation--the consequences of which are, at least partially, devastating. But I digress.

Karen Barad, in Meeting the Universe Halfway, offers an invaluable contribution to this thought process contained within the definition of intra-action. Intra-action "recognises that distinct agencies do not precede, but rather emerge through, their intra-action" (Barad 2007, 33). Interaction, in comparison, "assumes the prior existence of distinct entities" (197). Two significant details. One is temporal. The idea that, let's call it an entity, cannot know itself until it intra-acts with another entity. To know itself, an entity needs a context within which to recognise its significance. To know itself, an entity needs feedback. The knowing of itself, ergo does not emerge through division (doubt). Instead, it emerges through amalgamation.

The second is relational. The idea that meaning--value, purpose, you name it--emerges from intra-action. For meaning to emerge though intra-action, amalgamation, then, meaning must always emerge in hindsight.

\section{Imagine the consequences of (not just)}

\section{thinking \\ intra-action \\ instead \\ of}

\section{interaction between world and body,}


body and body, cell and cluster and peripheral nervous system. Imagine intra-action at every point of contact touched upon earlier in the text. 
In other words.

Always.

In other words. 


\section{performativity}

As a child I was taught to think of myself as weird and to expect my behaviour to be frowned upon. As a young teenager, I was taught to identify myself as flamboyant. My behaviour was decidedly girly, and obviously inappropriate for a boy (the 00s). Later on, I was taught to identify myself as a gay man (if I was lucky). I say "I was taught to think of myself as" because prior to having the experiences I am calling upon here I didn't relate to any of those terms; I didn't know that there is such a thing as "weird," or "flamboyant," or "gay." I didn't even know that sex and gender must be unnegotiably linked to one another. When I'm lucky these days, I am identified as a queer by some communities. A bisexual pansexual polyamorist and activist by others.

I stepped into this world and felt "wow, you can paint cartilage with colour," or "wow, there's a person that's really nice and attractive." It never occurred to me, until I received feedback, that there was "meaning" in these things. As I start from the point of naïveté and am being taught into a system that is unforgiving.

[...] words [...] made me realise something about intuition: that when something makes sense intuitively, especially at an early age, one can afford to not develop a critical understanding of whatever that thing that makes sense is. which is not noticeable, if what makes sense intuitively is the same thing that makes sense intuitively to most people around you. 
growing up queer, the way i learned that my intuitive understanding was "out of tune," culturally speaking, was through violence: i found myself bullied, made fun of, told that the things that made sense to me "made no sense," that $i$ should sort myself out, stop philosophising, making things complicated that supposedly aren't, that i should grow up or grow out of it. and so i started to develop a critical understanding of things $i$ never considered thinking critically about or studying because $i$ needed to survive, and because i needed to convince myself that i was not crazy.

by learning words and what they stand for, you learn that a discourse exists, that language exists, and by using (speaking) those words you 
learn that communities exist. by speaking about things that make sense you learn that you're not alone.

which, mind you, is not a principle that works for liberal feminists and queers alone. but that is another story for another time.

in closing, $i$ have to acknowledge the effort invested in inspiring members of the privileged majority to become critically aware of the things they never perhaps had to think about because those things never made them vulnerable, never isolated them socially. never put them on the spot.

the value of critical thinking, as i understanding it at the moment, is preventative: it prevents one 
from jumping to conclusions, from trusting assumption instead of evidence. and this goes to all people interested in relationships: catch yourself making assumptions instead of asking questions and work against that urge. teach yourself how to ask your partner questions! be interested in them. remember that they are a person, too. and when receiving answers, be brave. listen. digest. and take. your. time.

I// i love you. end of rant. (pavleheidler 2019a)

I come into the spotlight as a dancer and ... where do I begin? ${ }^{3}$ In the history of thought that I was educated in, I come on stage as a dancer to dominate the audience. (Much in the same way as to dance is to dominate the body, to be in control of the body.)

This is a colonial principle, isn't it, to assume that you not only can, but ought to come in and claim the space of the theatre as yours, that you ought to deliver and make everybody comply to your supposed talent and artistic genius. This principle is normalised, unionised even. Critics and spectators expect it to take place. Critics and spectators complain if it doesn't. They marginalise forms that don't comply by this principle as "research," and "experiment," and "I don't understand, it must have no value," and "is it even art." 
At the same time, as my research is becoming more palpable to me, I am beginning to realise that I come on stage--after all these years--only to shit my pants. STAGE FRIGHT, right? I start feeling bad about it, I start trying to eliminate it, because that's what one does, isn't it? Except that then I start reading, and thinking, and soon come up with the following proposal. What if stage fright isn't, in fact, the fright of performing? What if I am shitting my pants because I am starting to realise that all these people I am standing before are, in fact, people. Social animals who have a mind of their own, who have a history of their own, who have experience of their own. What if I feel uncomfortable because I was used to ignoring this realisation, because I was used to disrespecting the spectator's agential potential by treating them as a manipulatable generic member of the public. What if that's not the kind of politic I wish to embody anymore?

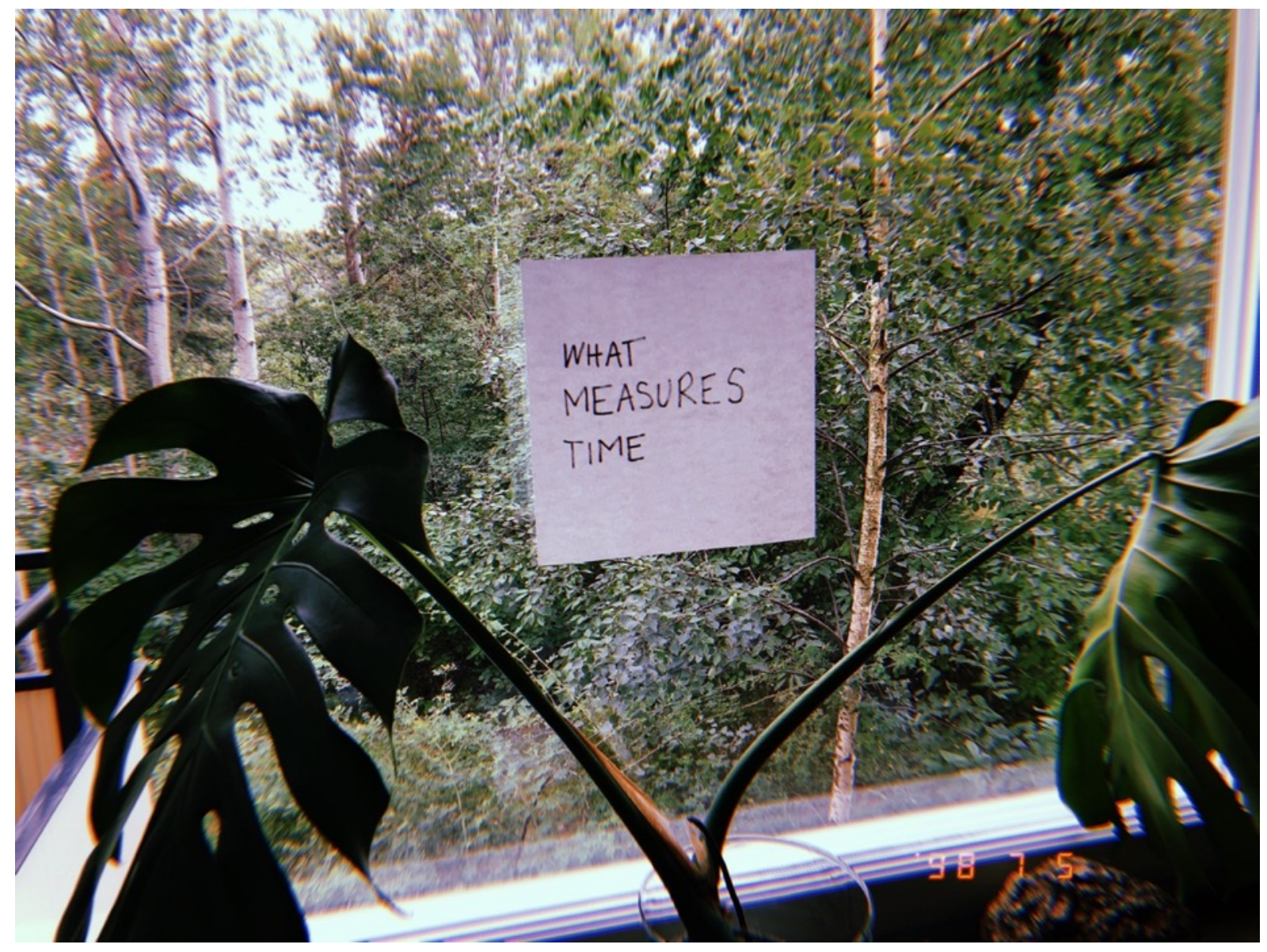

\section{Through being gendered I started understanding} something about performing, which is that so much of performance is not in my hands, as a performer. So 


\title{
much of performance is actually and literally in the gaze of those who are gazing at.
}

\author{
What can I do about that? \\ What can I do about any of that? \\ What can I do, as an individual? \\ What can I do about the institutionalised history of oppressive practices that teaches \\ me to be silent? That actively avoids teaching me how to speak?
}

\section{science-}

\section{fiction}

A series of circumstances put me in a situation which asked of me to address touch in my teaching. I've never before taught touch. In fact, most of my teaching by this point avoided touch at all costs. Touch is difficult for me, as it is difficult for every person who doesn't find touching and being touched intuitively easy. Meanwhile, there is little space in the professional context of dance and dance training that allows for the study of touch, that provides a slow approach to touch, and that encourages negotiation. Dancing is a culture that assumes touch, assumes everyone has an easy time touching and being touched, assumes that everyone wants to be touched, at all times, and 
for no explicit reason. Dancing is a culture that assumes that some things cannot be communicated except through touch. Dancing is a culture that doesn't necessarily have patience for those who put touch into question.

The class I developed for the occasion-and have been working on since-defines a practice that was going to be radically anti-colonial in its approach to consent. We practice asking for permission before touching every single time, we practice touching without ulterior motive, and without a previously prescribed agenda. We touch for the sake of study and are sensitive to what we learn from touching and being touched. We create the conditions for not-assuming touching. We wait, if needed. We negotiate: we ask questions and act according to the information we receive with the answers. And most importantly, we take the risk of never arriving at touching at all. I would like this record to show that we were going to practice methodologies I anticipated dancers to be well versed in. My plan was to do little more than remind participants of what they already knew.

It didn't take long for most participants, a lot of whom identified as highly sensitive and/or queer, to discover they tended to touch to manipulate. As long as the purpose of touching was to do, as long as touching was engaged in "with purpose," and as long as the person touching was in charge: the room was calm. But those techniques or habits were, of course, exactly the ones we set out to challenge.

What continues to surprise me is just how deeply challenging this work is turning out to be for the practitioner; how deeply moved persons will find themselves to be when they find themselves challenged at the level, so to speak, of assumption. When they find themselves conscious of the way and the speed in which their thinking conditions their doing.

\section{When awakened, however temporarily,}

to powerlessness: will, or mind, can feel into the time before the condition of the body emerges (is remembered). It is then that one can imagine how much willed, and mind-full labour might be necessary 


\section{for the re-conditioning of not just habit, but the physical condition at large.}

It seems to me that when one starts exercising the will, the mind, or the I in fact, that internalised entity that speaks as I, one discovers that this I is a mobile thing that can manifest in the body in different ways, one discovers that this I can speak and stay quiet, i.e., that it can manifest through language or sensation. I speculate when I say that the discovery of the I as dynamic and as sensitive to the condition that makes it is provocative of discomfort. Because people, and here I am reporting on a pattern I am recognising, run the risk of losing their sense of self when they acknowledge that they are more than the assumed singular. More than that learned sense of I--stable-am moving things in this life--unstable--, right? I-stable--am in charge--of everything unstable, i.e., life on Earth.

I think that the acknowledgement of this discomfort begins the process of actually learning how to think. In which case by thinking I am addressing an embodied experience. An experience that takes fantasy to be a part of daily life and takes it seriously. And starts treating it with, I don't want to say respect, but as if it has agency, as if it has a voice, as if it has a stake in reality, and as if it's something that you are in dialogue with. Which it does. And you are. As far as I'm concerned.

I say fantasy because I do not know of a better way to frame at the moment what it is that I am going on about. What I do know is that I am not talking about a therapeutic process per se. I am not talking about efforts that are interested in being recognised as psychology, psychiatry, neurology, medical anatomy, or medicine in general. I am talking about an inquiry into critical thinking, where thinking is embodied; an inquiry that cannot not take sensing and feeling into account. An inquiry that cannot not take chaos as its structural element. An inquiry that cannot not benefit from crying in public, that cannot not disrupt the order of comfort. An inquiry that cannot not challenge the assumed measure of appropriateness, and in some cases: the temporary and culturally specific measure of sanity.

The reason I am interested in engaging with this practice is for the potential consequence with which it might merit its practitioners. To go back to the example of performing: how can I dominate someone else, in this case, the audience, if I cannot dominate myself to begin with? Or the other way around, how does my experience of me being more than one complexify my understanding of what it means to work with an audience, to work with the public, to work with people? And how do I learn to start working with this, in a world in which an employee is rarely if ever paid to be engaged in a personal study as well as be engaged with labour the employer is to directly benefit from? How do I start working with this, when speaking up is recognised as rebellious, unproductive, and assumed to be threatening--when creativity, and authorship is reserved for those who inhabit the higher places in the food chain? 
An example of an exercise:

When working on touch, I will often train my will, my mind, the speaking I, to withdraw from the space of the hand and so let the hand perceive in its own right.

When working on touch, I (remember: capacity of the central nervous system) will often train my will, my mind, the speaking I, to withdraw from the space of the hand (remember: the capacity of cellular life) and so let the hand perceive in its own right. 
The challenge is then in the question: how does my process change given the circumstances of the exercise? How does entertaining this or a similar scenario change my place in the politic of how I relate to other materials in and of this Universe?

It is an ever-so-slightly humbling experience, to take your-self as selves seriously. It awakens us to the fact that wherever we're found at the moment of consciousness is... real. 
An example of a poem discovered during exercise:

We are an amalgamation of what can and cannot be known consciously, cognitively at any one time. We act, and in action engage the world in a relationship we are and cannot necessarily be in control of at the same time. We can only ever be partially obedient. Digestion is also always at work. It has a life of its own. We have a life of our own. We are and is me and we are and is not. We are 
and is of me, and we are and is not; and I am of we, and I am not. OR am I? Are we? 
just

because you

don't

understand it

doesn't 


\section{mean it}

\section{doesn't}

\section{exist}

\section{Notes}

1 "The histories that bring us to feminism are the histories that leave us fragile" (Ahmed 2017, 22).

2 "Intra-actions are nonarbitrary, nondeterministic causal enactments through which matter-in-the-process-ofbecoming is iteratively enfolded into its ongoing differential materialisation. Such a dynamics is not marked by an exterior parameter called time, nor does it take place in a container called space. Rather, iterative intra-actions are the dynamics through which temporality and spatiality are produced and iteratively reconfigured in the materialisation of phenomena and the (re)making of material-discursive boundaries and their constitutive exclusions" (Barad 2007, 179).

3 "Discursive practices are the material conditions for making meaning. In my [Karen Barad's] posthumanist account, meaning is not a human-based notion; rather, meaning is an ongoing performance of the world in its differential intelligibility. Intelligibility is usually framed as a matter of intellection and therefore a specifically human capacity. But in my agential realist account, intelligibility is a matter of differential responsiveness, as performatively articulated and accountable, to what matters. Intelligibility is not an inherent characteristic of humans but a feature of the world in its differential becoming. The world articulates itself differently" (Barad 2007, 335). 


\section{Works Cited}

Ahmed, Sara. 2017. Living a Feminist Life. Durham, NC: Duke University Press.

https://doi.org/10.1215/9780822373377

Barad, Karen. 2007. Meeting the Universe Halfway: Quantum Physics and the Entanglement of Matter and Meaning. Durham, NC: Duke University Press. https://doi.org/10.1215/9780822388128

brown, adrienne maree. 2017. Emergent Strategy: Shaping Change, Changing Worlds. Chicago: AK Press.

Braidotti, Rossi. 2013. The Posthuman. Cambridge: Polity Press.

Butler, Judith. 1990. Gender Trouble. New York and London: Routledge.

Cohen, Bonnie Bainbridge. 2012. Sensing, Feeling, and Action: The Experimental Anatomy of Body-Mind Centering®. Toronto: Contact Editions.

Descartes, Réne. 2006. A Discourse on the Method of Correctly Conducting One's Reason and Seeking Truth in the Sciences. Translated by lan Maclean. Oxford: Oxford University Press.

Haraway, Donna J. (1985) 2000. "A Cyborg Manifesto: Science, Technology and Socialist-Feminism in the Late Twentieth Century." In The Cybercultures Reader, edited by David Bell and Barbara M. Kennedy, 291-324. London and New York: Routledge.

_- 2 2016. Staying with the Trouble: Making Kin in the Chthulucene. Durham, NC: Duke University Press. https://doi.org/10.1215/9780822373780

Harney, Stefano, and Fred Moten. 2013. The Undercommons: Fugitive Planning and Black Study. New York: Autonomedia.

Kumashiro, Kevin. 2002. Troubling Education: Queer Activism and Antioppressive Education. New York and London: RoutledgeFalmer.

Lorde, Audre, ed. (1977) 2017. Your Silence Will Not Protect You. San Jose, CA: Silver Press.

Muñoz, José Esteban. Queering Utopia: The Then and There of Queer Futurity. New York: New York University Press.

pavleheidler. 2019a. "i read through this list and think i did a favour to myself." Facebook, July 1, 2019: https://www.facebook.com/pavleheidler/posts/10157438251672164

_-_. 2019b. "dances writing poetry no⒌" Filmed May 2019 at Earthdance, MA, USA. Video, 11:21.

https://vimeo.com/338119358

Spatz, Ben. 2015. What A Body Can Do: Technique as Knowledge, Practice as Research. New York and London: Routledge. https://doi.org/10.4324/9781315722344

UC Berkeley Department of Molecular and Cell Biology. "The Nervous System." Accessed November 5, 2019. https://mcb.berkeley.edu/courses/mcb135e/nervous.html

Wikipedia. "Stem cell." Accessed November 10, 2019. https://en.wikipedia.org/wiki/Stem_cell\#Embryonic

featured artworks

pavleheidler, 2017. Without duration, time. Photograph.

pavleheidler, 2019. ASKA \#1. Drawing.

pavleheidler, 2019. What measures time. Photograph.

pavleheidler, 2018. just because you don't understand it doesn't mean it doesn't exist. Poem. 
pavleheidler (they/them) has been dancing-performing, studying, writing, and teaching dancing professionally since early teenage-hood; inevitably considering their varied engagements with the field of experimental dancing and choreography - where choreography is understood to be an expanded practice - as opportunities to continue studying the notion and the practice of (1) embodiment, (2) performativity, (3) relationality, and (4) successful communication.

they studied at the Salzburg Experimental Academy of Dance, graduated from the Performing Arts Research and Training Studios in 2012, and took their MFA degree in Choreography-specialisation-Performance from the University of Dance and Circus at the Stockholm University of the Arts in 2015. They are currently studying BodyMind Centering® with Embody-Move, UK.

pavleheidler is the recipient of the 2018 International Choreographer's Stipend awarded annually to a Swedish dance artist by the Swedish Arts Grants Committee.

(C) 2020 pavleheidler

(c) (i) (2) Except where otherwise noted, this work is licensed under a Creative Commons Attribution-

(c) 